\title{
Efficacy of Aloe secundiflora Crude Extracts on Ascaridia galli in Vitro
}

\author{
Fredrick Kaingu ${ }^{1,2,4}$, Alfred Kibor ${ }^{2}$, Rebecca Waihenya ${ }^{4}$, Robert Shivairo ${ }^{2} \&$ Lewis Mungai $^{3}$ \\ ${ }^{1}$ Ministry of Livestock Development, Malindi, Kenya \\ ${ }^{2}$ Animal Health Group, Department of Animal Sciences, Egerton University, Egerton, Kenya \\ ${ }^{3}$ Department of Biological and Biochemistry Sciences, Egerton University, Egerton, Kenya \\ ${ }^{4}$ Department of zoology, Jomo Kenyatta University of Agriculture and Technology, Nairobi, Kenya \\ Correspondence: Fredrick Kaingu, Ministry of Livestock Development, Malindi, Kenya. Tel: 254-726-427-400. \\ E-mail: kaingufred@yahoo.com,kaingufred@gmail.com
}

Received: September 17, 2012 Accepted: November 28, 2012 Online Published: December 15, 2012

doi:10.5539/ sar.v2n2p49

URL: http://dx.doi.org/10.5539/sar.v2n2p49

\begin{abstract}
Aloe secundiflora Synonym: Aloe floramaculata, Aloe marsabitensis, Aloe engleri belongs to the family Asphodelaceae. Aloe leaf gel and Aloe exudates are the main components. The gel is derived from parenchytomous cells while exudates are derived from the inner epidermal layers. The gel consists of mainly polysaccharides while the exudates consists of a mixture of phenolic compounds mainly athrones, chromones and phenyl pyrones. Leaf components of Aloe have been credited for antibacterial, antifungal and antiviral and anthelmintic medicinal properties. The effectiveness of Aloe secundiflora extracts on the most prevalent nematode of chicken Ascaridia galli was conducted in vitro. The results of this study indicate that Hexane, Ethylacetate, Acetone, Methanol and chloroform extracts were found active in hindering the development of Ascaridia galli eggs to larval stage three $\left(\mathrm{L}_{3}\right)$, and this was dependent on the concentration of the crude extract. The lowest concentration of the various extracts $(5 \mathrm{mg} / \mathrm{ml})$ had an inhibition percent (IP), 75.52\%, 79.60\%, $87.21 \%, 86.13 \%$ and $43.6 \%$ respectively. The highest concentration of the extracts was $(50 \mathrm{mg} / \mathrm{ml})$, at this level the inhibition percent was found higher than in the lowest extracts concentrations i.e., 91.84\%, 97.55\%, 100\%, $99.46 \%$ and $91.29 \%$ respectively. Aloe secundiflora extracts therefore have inhibitory effects on the Ascaridia galli larval development in vitro. Phytochemical tests on the extracts revealed the presence of various chemical compounds.
\end{abstract}

Keywords: efficacy, Aloe secundiflora, extracts, antihelmintic, in vitro

\section{Introduction}

\subsection{Problem Statement}

Free-range chickens are known to suffer a wide range of common parasitic diseases throughout the world due to the scavenging habits. Prevalence studies by Permin et al. (1997) indicated that almost $100 \%$ of the local chickens are infected by a wide range of ecto-parasites, endo-parasites and haemoparasites. This has lead to poor performance of Indigenous chicken in Kenya and to a large extent in Africa.

\subsection{Importance of the Problem}

The reliance on synthetic anthelmintics which are highly costly and inaccessible in many developing countries may present a challenge in the management and elimination of Gastro-Intestinal parasite infections in chicken necessitating new alternative ways of helminthes and parasites control. As result of these challenges, pastoralists and Small Holder Farmers have continued to apply Ethno-veterinary Medicine. This is possible where indigenous knowledge has been used to identify indigenous plants as livestock dewormers (Danø \& Bøgh, 1999). The application of Ethno veterinary medicine presents an affordable, sustainable alternative if the compounds were scientifically evaluated to be useful.

\subsection{Research Scholarship}

Aloe secundiflora leaves species have been known for their medicinal uses since the $4^{\text {th }}$ century. Leaf components of Aloe have been credited for medicinal properties antibacterial, antifungal and antiviral (Avilla et 
al., 1997). The leaf exudate of this species has found ethno-veterinary use for treatment of bacterial diseases and parasites and in management of viral diseases. In poultry for example the exudates has been extensively used as prophylaxis for Newcastle diseas and as therapeutic for fowl typhoid, coccidiosis and other enteric conditions (Waihenya et al., 2003). Analytical High Performance Liquid Chromatography-Mass Spectropy (HPLC-MS) studies of the exudates have shown that it consists of a mixture of phenolic compounds or aliphatic compounds (Waihenya et al., 2003). This research was carried out to assess the anthelmintic activity of Aloe secundiflora extracts in vitro using the nematode parasite Ascaridia galli in larval development assays.

\subsection{Hypotheses}

$H_{O}$ : Aloe secundiflora crude extracts do not inhibit larval development of Ascaridia galli in vitro.

$H_{O}$ : Viable Ascaridia galli eggs do not grow to $\mathrm{L}_{3}$ larvae when grown in Phosphate Buffered Saline.

Ho: Aloe secundiflora extracts do not show presence of chemical compounds on phytochemical analysis (tests).

\section{Materials and Methods}

\subsection{Plant Collection and Identification}

Aloe secundiflora leaves were collected from Chemeron Research substation in Marigat location Baringo district. They were identified at Egerton University, Njoro, and the voucher specimen number SK62, stored in the herbarium. A total of $5 \mathrm{~kg}$ fresh of Aloe secundiflora leaves were chopped using a machete. The materials were put in a rotary blender and blended to slurry and transferred to Winchester glass bottles.

The extraction of the various fractions was carried as follows: To each Winchester bottle containing the crude extract of Aloe secundiflora was added to one liter Hexane solvent and thoroughly mixed then left overnight at room temperature. The following day the solute was decanted into 2 clean half liter beakers and to each were added three spatulas of sodium sulphate and four spatulas of activated carbon charcoal. Then filtration followed using a filter paper of gauge $1-215 \mathrm{~mm} \varnothing$ to obtain a clear filtrate. The filtrate was concentrated in a round bottomed flask at temperature of $50^{\circ} \mathrm{C}$ using a rotavapor machine connected to a vacuum pump and a condenser machine to recover the hexane solvent. The concentrated solution was put in small glass universal bottles and covered with perforated aluminum foil for air drying the samples. A cream extract was obtained and denoted ASH (Aloe secundiflora Hexane extracts).The same procedure was used to obtain Ethyl acetate, Chloroform, Acetone and Methanol extracts).

Weight of approximately $5.164 \mathrm{~kg}$ of fresh Aloe secundiflora leaves were chopped and blended to slurry material to obtain the five solvent extracts. A crude extract was also obtained by crushing fresh leaves using a blender and squeezing the fresh crude extract viscous juice and stored in a refrigerator. This is neat extracts, without solvent extraction processes.

\subsection{Parasite Collection}

Specimens of adult Ascaridia galli worms were collected in 0.9 phosphate buffered saline $\mathrm{pH} 7.3$, from the intestines of freshly necropsied local chicken (Gallus gallus domesticus). The method used to obtain Ascaridia galli eggs begins with the collection of adult Ascaridia galli parasites from the intestines of indigenous birds, from Nakuru Indigenous Chicken abattoir. Parasites were washed with distilled water and diluted using formalin solution to avoid contamination. The worms were opened under a dissecting microscope; their uteri were located and squeezed to liberate the ova (eggs). The eggs obtained from the intestines were washed several times using phosphate buffered saline (PBS), then were sedimented through centrifugation at $2000 \mathrm{rpm}$ and finely dispersed in $2 \%$ hydrated copper sulphate $\left(\mathrm{CuSO}_{4} 7 \mathrm{H}_{2} \mathrm{O}\right)$ solution. The eggs were finally stored in room temperature before they were used after viability test was done. This method is a modification from the in-vitro larval migration inhibition test as described by Permin et al. (2002).

\subsection{Phytochemical Tests}

The following phytochemical tests were performed to detect the presence and absence of chemical compounds in Aloe secundiflora extracts. Polysaccharides (acid hydrolysis test), Aliphatic compounds test (bromine test) and acetylide test, Phenolic compounds test, Terpenoids test (salkowski test) with warming and non-warming tests, athracene test and glycosides test. Thin layer chromatography analysis was also performed on the extracts.

\subsection{In Vitro Screening of Plant Extracts}

Laboratory evaluation of anthelmintic activity of Aloe secundiflora extracts was done using Ascaridia galli viable eggs recovered as described earlier. The Percent Inhibition (PI) of larval development was calculated using the formula (Rabel et al., 1994): 


\section{Percent Inhibition $=\left\{1-\frac{\mathrm{T}}{\mathrm{C}}\right\} \times 100$}

Where $\mathrm{C}$ is the number of eggs that developed to $\mathrm{L}_{3}$ in the control incubations and $\mathrm{T}$ is the number of eggs that developed to $\mathrm{L}_{3}$ larvae in incubations containing different concentrations of various plants extracts tested.

Five types of extracts were used: Hexane extract, Ethylacetate extract, Acetone extract, Methanol extract and Chloroform extract. In each extract the following concentrations were used: $5 \mathrm{mg} / \mathrm{ml}, 10 \mathrm{mg} / \mathrm{ml}, 20 \mathrm{mg} / \mathrm{ml}$, $40 \mathrm{mg} / \mathrm{ml}$ and $50 \mathrm{mg} / \mathrm{ml}$. Each concentration was replicated four times. There were three control groups: neat, dimethylsulphuxode (DMSO) and phosphate buffer saline. Each well had a total volume of $1 \mathrm{ml}$ with 100 viable eggs of Ascaridia galli which were incubated at a temperature of $25-26^{\circ} \mathrm{C}$ for 28 days. The contents in each well were microscopically examined using an inverted microscope; developed $\mathrm{L}_{3}$ larvae and undeveloped/destroyed eggs were counted and recorded. Averages on the four replicates were used to calculate the Inhibition Percent (IP) of each extract and compared to the controls.

\section{Results}

\subsection{Phytochemical Analysis}

The phytochemical tests were performed to detect the presence of chemical compounds. Table 1 shows the types of chemical compounds found in Aloe secundiflora extracts. The test for the presence of tannins in Aloe secundiflora extracts by the use of $0.1 \%$ Ferric chloride was undetectable in four extracts, which were pale brown in color, while methanol extract was brown greenish in colour, indicating the presence of tannins. Acid hydrolysis test was used to test the presence of polysaccharides in Aloe extracts. Two tests were performed for polysaccharides test; the bromine test which test the presence of multiple bonds (double or triple bonds) and the acetylide test which tests the presence of a triple bond (alkynes), Aloe secundiflora chloroform extract and Aloe secundiflora acetone extract tested positive for the presence of terminal alkynes by forming grayish white precipitate. Phenolic compounds were found positive in Aloe secundiflora methanol extract, the Ferric chloride solution turned to a blue green colour, this indicated the presence of phenolic compounds, and the rest of the extracts tested negative. Salkowski test was used to test the presence of terpenoids. Two test were used; with warming and non-warming. The five extracts namely methanol, acetone, chloroform, ethyl acetate and hexane extract had a red to reddish brown color, this is a positive test for the presence of terpenoids, all extracts had terpenoids compounds. Glycosides compounds were only present in Aloe secundiflora acetone extract, which formed a red precipitate, while the other four extracts tested negative.

Table 1. Types of chemical compounds found in Aloe secundiflora extracts

\begin{tabular}{lllllll}
\hline \multicolumn{2}{l}{ Aloe secundiflora extracts } & & & \\
& Compound test & Hexane & Ethylacetate & Acetone & Methanol & Chloroform \\
\hline 1 & Tannin test & $(-\mathrm{ve})$ & $(-\mathrm{ve})$ & $(-\mathrm{ve})$ & $(+\mathrm{ve})$ & $(-\mathrm{ve})$ \\
2 & Aliphatic compounds & $(+\mathrm{ve})$ & $(+\mathrm{ve})$ & $(+\mathrm{ve})$ & $(+\mathrm{ve})$ & $(+\mathrm{ve})$ \\
3 & Acetylide test/Terminal alkynes & $(-\mathrm{ve})$ & $(-\mathrm{ve})$ & $(+\mathrm{ve})$ & $(-\mathrm{ve})$ & $(+\mathrm{ve})$ \\
4 & Phenolic compounds & $(-\mathrm{ve})$ & $(-\mathrm{ve})$ & $(-\mathrm{ve})$ & $(+\mathrm{ve})$ & $(-\mathrm{ve})$ \\
5 & Terpenoids test (salkowski test). & $(+\mathrm{ve})$ & $(+\mathrm{ve})$ & $(+\mathrm{ve})$ & $(+\mathrm{ve})$ & $(+\mathrm{ve})$ \\
6 & Athracene test & $(-\mathrm{ve})$ & $(-\mathrm{ve})$ & $(-\mathrm{ve})$ & $(-\mathrm{ve})$ & $(-\mathrm{ve})$ \\
7 & Glycosides test & $(-\mathrm{ve})$ & $(-\mathrm{ve})$ & $(+\mathrm{ve})$ & $(-\mathrm{ve})$ & $(-\mathrm{ve})$ \\
\hline
\end{tabular}

KEY: (+ve) = detectable, (compound present); (-ve) = undetectable, (compound absent).

\subsection{Inhibitory Effects}

In the in vitro tests with Hexane, Ethylacetate, Acetone, Methanol and chloroform extracts inhibited larval development of Ascaridia galli eggs. This inhibition was dependent on the concentration of the extract. The lowest concentration of the various extracts $(5 \mathrm{mg} / \mathrm{ml})$ had an inhibition percent (IP), $75.52 \%, 79.60 \%, 87.21 \%, 86.13 \%$ and $43.6 \%$ respectively. The highest concentration of the extracts was $50 \mathrm{mg} / \mathrm{ml}$. At this level percentage inhibition was found higher than in the lowest extracts concentrations i.e. $91.84 \%, 97.55 \%, 100 \%, 99.46 \%$ and 
91.29\% respectively. The crude aqueous extract was a natural extract from Aloe secundiflora; it is composed of all the five types of extracts. It had an inhibition percent ranging from $93.05 \%-99.46 \%$. Phosphate Saline Buffer (PBS) acted as the negative control. The 100 Ascaridia galli eggs incubated in phosphate saline buffer (control) had an average of $91.9 \%$ developing to larval stage three $\left(\mathrm{L}_{3}\right)$. This control mean was used to calculate percent inhibition (Rabel et al., 1994). Inhibited eggs were conspicuously destroyed in shape, morphologically distorted shapes and curvatures while some preserved the egg shape but the larvae did not develop to motile $\mathrm{L}_{3}$.

Figure 1 shows the percentage inhibitions of various extracts in different concentrations. The activity of Aloe secundiflora acetone (ASA) extract increased exponentially from $87.21 \%-100 \%$ with an increase of concentration $10 \mathrm{~g} / \mathrm{ml}$. The higher the activity of an extract at lower dose concentrations, the more effective the extract. Further increase of the concentration of the ASA had no effect as the graph from this point reaches the plateau phase, a steady straight line. The activity of the ASA extract could have been a result of the anthelmintic active ingredients; glycosides and terpenoids as determined by the phytochemical tests that were performed (Table 1). Glycosides and terpenoids are active principles against nematodes (Mwamachi et al., 2003; Onyelili et al., 2001).

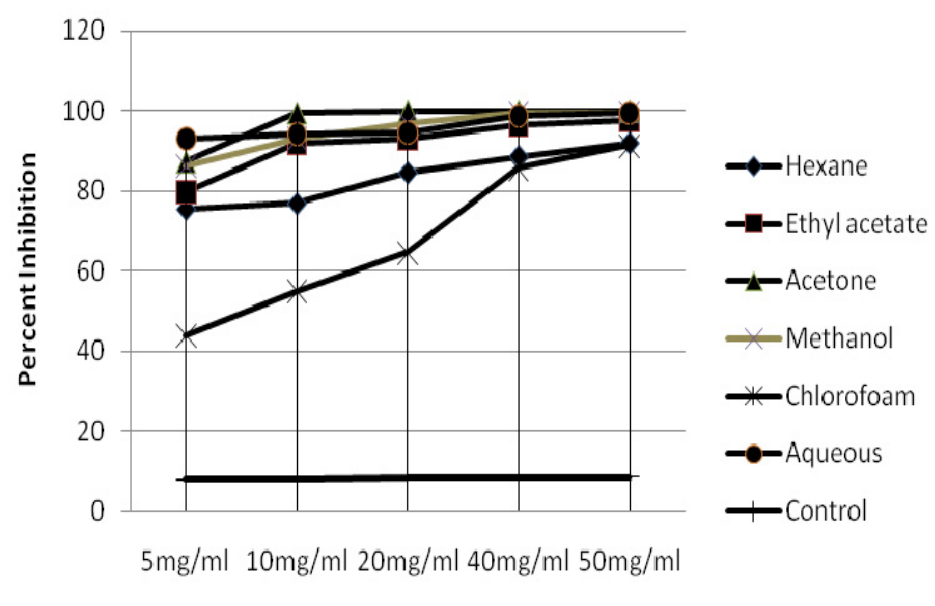

Concentrations

Figure 1. Percentage inhibitions of various extracts in different concentrations

Aloe secundiflora ethyl acetate (ASE) extract inhibition line graph increased at an increasing rate from $91.84 \%$ at $5 \mathrm{mg} / \mathrm{ml}$ to $96.46 \%$ at $40 \mathrm{mg} / \mathrm{ml}$ and thereafter increased at a decreasing rate to $97.55 \%$ at $50 \mathrm{mg} / \mathrm{ml}$. The activity of ASE extract could have been contributed by the chemical compounds present i.e. aliphatic compounds and terpenoids (Table 1). Comparing the activities of Aloe secundiflora chloroform (ASC) extract and Aloe secundiflora hexane (ASH) extracts, though ASC activity is very low at $5 \mathrm{mg} / \mathrm{ml}$ at $43.6 \%$, in contrast ASH extract high at $75.52 \%$, the two extracts rise steadily to converge to a common point at $92 \%$ inhibition percent at highest concentration of $50 \mathrm{mg} / \mathrm{ml}$ (Figure 1). The activity of these two extracts could have been contributed by the chemical compounds present (Table 1). The IP in natural crude extracts was found high, $93.05 \%$ even at the low concentration of $5 \mathrm{mg} / \mathrm{ml}$, the IP increased with increase in concentration to $99.46 \%$ at $50 \mathrm{mg} / \mathrm{ml}$. The control used was Phosphate Buffered Saline. The PBS is conducive for larval development.

\section{Conclusion}

Crude extracts of Aloe secundifora have an inhibitory effect on the development of larval stages of Ascaridia galli in vitro. Acetone and crude aqueous extracts had the highest anthelmintic activity with lyses of larval stages and highest inhibition percentages. The inhibitory effect depends on the concentration of the extract used. The five solvent extracts used have different active principles and thus difference in activity against the larvae stages of Ascaridia galli in vitro. The use of crude aqueous extracts of Aloe secundiflora as an anthelmintic by the poor resource farmer is highly recommended; though the study was based on in vitro experiments the results can be inferred for application in the indigenous chicken (in vivo). Further in vivo experiments on Aloe secundiflora extract or possibly bioactive compounds that will incorporate toxicology /residue studies are required before it can be recommended for safe use in poultry and other domestic animals. Dose determination and confirmation studies are necessary further anthelmintic evaluation. 


\section{Acknowledgement}

The authors acknowledge the Kenya Agricultural Productivity Project for funding this study and Egerton University (EU), Ministry of Livestock Development (MoLD) and the Kenya Agricultural Research Institute in Naivasha for provision of research facilities.

I would also like to thank Dr R.S Shivairo for the technical support he offered from data collection, processing and analysis. Mr. Richard Kosgey and Mr. Lewis Mungai are enormously appreciated for the challenging work in analyzing samples in the laboratory. The technical work on Aloe extraction is indebted to Mrs. Regina chepkorir a laboratory technician in Biochemistry Egerton University.

\section{References}

Avila, H., Rivero, J., Herrera, F., \& Fraire, G. (1997). Cytotoxicity of low molecular weight fraction from Aloe vera (Aloe vera barbadensis miller gel). Toxicon., 35(9), 1423-1430. http://dx.doi.org/10.1016/S0041-0101(97)00020-2

Carter, S. (1994). In Flora of Tropical East Africa. Prepared at Royal Botanic Gardens (Ed.). R. M. Poihill, A. A. Balkema / Rotterdam Brookfield.

Femenia, A., Sanchez, E., Simal, S., \& Rossello, C. (1999). Compositional features of polysaccharides from Aloe

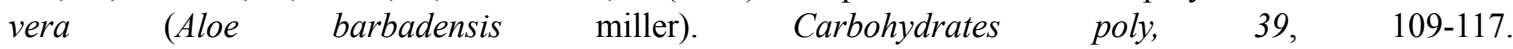
http://dx.doi.org/10.1016/S0144-8617(98)00163-5

Jovellanos, J. M. (1997). Efficacy of three selected herbal plants on gastro-intestinal parasites of cattle. DVM. University of the Philippines, Department of veterinary Parasitology. p. 36

Mwamachi, D. M., Mukendi, F. M., Omondi, G. W., \& Sigilai, P. M. (2003). Worm infestation in indigenous chickens: seasonal variation as a guide to strategic control in the coastal sub humid zones of Kenya. In: First Adaptive Research Conference, KARI Headquarters, Kenya.

Onyelili, P. A., Nwosu, C. O., Amin, J. D., \& Jibike, J. I. (2001). Anthelmintic activities of crude aqueous extract of Nauclea latifolia stem bark against ovine nematodes. Filoterapia, 72, 12-21. http://dx.doi.org/10.1016/S0367-326X(00)00237-9

Permin, A., Esmann, J. B., Hoj, C. H., Hove, T., \& Mukaratirwa, S. (2002). Ecto-, Endo and Haemoparasites in Free range chickens in the Goromonzi District, Zimbabwe. Preventive Veterinary Medicine, 54(3), 213-224. http://dx.doi.org/10.1016/S0167-5877(02)00024-7

Rabel, B., McGregor, R., \& Douch, P. G. C. (1994). Improved bioassay for estimation of inhibitory effects of ovine gastrointestinal mucus and anthelmintics on nematode larval migration. International Journal for Parasitology, 24, 671-676. http://dx.doi.org/10.1016/0020-7519(94)90119-8

Vierra, L. S., Cavalcante, A. C. R., Pereira, M. F., Dantas, L. B., \& Ximens, L. J. F. (1999). Evaluation of anthelmintic efficacy of plants available in Ceara state, North- east Brazil for the control of goat gastro-intestinal nematodes. Revue de medicine Veterinaire, 150, 447-452.

Waihenya, R. K., Oliver, K., Hansjorg, H., Karl, H Z., Mtambo, M. M. A., \& Nkwegulila, G. (2003). The phytochemical profile and identification of main phenolic compounds from the leaf exudates of Aloe secundiflora by high performance liquid chromatography-mass spectropy. Phytochemical analysis, 14, 83-86. http://dx.doi.org/10.1002/pca.682 